Article

\title{
Crenal Habitats: Sources of Water Mite (Acari: Hydrachnidia) Diversity
}

\author{
Ivana Pozojević ${ }^{1}$, Vladimir Pešić ${ }^{2}$, Tom Goldschmidt ${ }^{3}$ and Sanja Gottstein ${ }^{1, * \mathbb{C}}$ \\ 1 Department of Biology, Faculty of Science, University of Zagreb, Rooseveltov trg 6, 10000 Zagreb, Croatia; \\ ivana.pozojevic@biol.pmf.hr \\ 2 Department of Biology, University of Montenegro, Cetinjski put b.b., 81000 Podgorica, Montenegro; \\ vladopesic@gmail.com \\ 3 Zoologische Staatssammlung, Münchhausenstraße 21, D-81247 München, Germany; \\ tomgoldschmidt@web.de \\ * Correspondence: sanja.gottstein@biol.pmf.hr
}

Received: 29 July 2020; Accepted: 17 August 2020; Published: 20 August 2020

\begin{abstract}
Many studies emphasized the role that water mites play within the invertebrate communities of spring ecosystems, regarding species diversity and its significance within the crenal food web, as well as the specific preferences water mites exhibit towards spring typology. In pristine natural springs with permanent flow, water mites are nearly always present and usually display high diversity. This study aimed to determine whether significant differences in water mite assemblages between rheocrene (river-forming springs with dominant riffle habitats) and limnocrene (lake-forming springs with dominant pool habitats) karst springs could be detected in terms of species richness, diversity and abundance, but also in different ratios of specific synecological groups: crenobiont (exclusively found in springs), crenophilous (associated with springs) and stygophilous (associated with groundwater) water mite taxa. Our research was carried out on four limnocrenes and four rheocrenes in the Dinaric karst region of Croatia. Seasonal samples (20 sub-samples per sampling) were taken at each spring with a $200-\mu \mathrm{m}$ net, taking into consideration all microhabitat types with coverage of at least $5 \%$. Water mite abundance was found not to differ between morphological spring types. Significantly higher values of species richness and diversity indices were found in rheocrenes compared to limnocrenes, like those usually reported for this type of springs. However, unlike the studies previously reported, in this case, the higher shares of crenophilous and crenobiont water mite individuals were found in limnocrenes. The differences between stygophilous water mite taxa ratios among spring morphotypes were not statistically significant, indicating that the degree of the groundwater/surface water interaction (and water mite interaction therein) does not seem to be directly influenced by spring morphotype. Within this research, $40 \%$ of identified water mite species (eight out of twenty) were recorded for the first time in Croatia, thus highlighting again a huge gap in water mite knowledge of karst springs.
\end{abstract}

Keywords: spring ecology; crenal diversity; crenal water mites; spring morphology

\section{Introduction}

Springs are unique and complex ecosystems that house an array of different synecological groups of invertebrate species: from euryvalent generalist species, to highly specialized stenovalent crenobiont species (exclusively found in springs), as well as species that cohabitate between groundwater/surface water and aquatic/terrestrial habitats [1-4]. The eucrenal zone is frequently inhabited by stygophilous species (associated with groundwater), who depend on surface water habitats mostly for feeding and other biotic purposes and interactions [5]. Karst springs differ from other spring types usually by 
a higher degree of discharge heterogeneity and water level fluctuations [6,7] that are a result of the permeability of karstic geological layers [8]. Based on the classical Steinmann-Thienemann limnological spring classification, springs are usually categorized by ecomorphotype, as it is considered to be the key defining factor in determining crenal communities. Three main morphotypes include limnocrenes (lake-forming springs), rheocrenes (river-forming springs) and helocrenes (swamp-forming spring; [9]). In this research, we focused on limnocrene and rheocrene karst springs of Croatia. These springs mainly differ in water retention time and/or flow velocity that consequently influence an array of environmental parameters [7].

Most water mite species show clear preferences for specific habitats [10]; in fact, water mites are considered to be the invertebrate group with the highest ratio of crenophilous and crenobiont taxa (approximately 20\%, [11,12]). Two are major crenobiont groups suggested by Gerecke et al. [11] that are called "paleocrenobiont" and "neocrenobiont" water mite species. Paleocrenobiont species include water mites from the superfamily Hydryphantoidea and represent evolutionary "older" species, developed from terrestrial ancestors, that inhabited the freshwater systems with a relatively large and stable transition zone between terrestrial and aquatic habitats-ponds and springs [13]. Neocrenobiont species are derived from rhithrobiont species that have secondarily inhabited spring ecosystems by upstream migration. This group of species is usually dominant in rheocrenes, where we usually find the mentioned rheocrenobionts, other crenobionts not specific to a morphotype, but also rhithrobiont species [14]. Limnocrenes are often inhabited by non-specific crenobionts because in Europe it is commonly believed that no true limnocrenobiont water mite species are documented, although a recent study suggests that large karstic limnocrenes on the Balkan peninsula (Ecoregion 5 and 6 by Illies [15]) may be inhabited by true limnocrenobionts [16]. Nevertheless, because of the aforementioned reasons, rheocrenes usually display higher water mite diversity.

The main focus of this study was to analyse water mite diversity in spring habitats with four specific goals in mind: (1) to analyse differences in environmental parameters between limnocrenes and rheocrenes and their influence on water mite assemblage composition; (2) to determine differences in water mite species richness, abundance and diversity indices between the two spring ecomorphotypes; (3) to analyse the differences in ratios of specific synecological groups (stygophilous and crenophilous/crenobiont taxa) between the ecomorphotypes and (4) to determine which water mite species contribute most to the similarity within a spring ecomorphotype.

\section{Materials and Methods}

\subsection{Study Area}

The study area is located in the Dinaric Western Balkan ecoregion [15] of Croatia. Within the study area, four river-forming springs—rheocrenes—and four lake-forming springs—limnocrenes [9]—were selected: rheocrenes Čabranka, Zrmanja, Krčić, Žrnovnica and limnocrenes Kupa, Kamačnik, Una, Cetina (Figure 1).

Each spring was sampled four times, once per season in 2015/2016. On every sampling occasion, 20 subsamples were taken with regard to microhabitat composition. Only microhabitat types that made up at least $5 \%$ of the total substrate mosaic were sampled [17]. A total of 640 benthic macroinvertebrate (sub)samples were collected ( 80 per spring, 320 from each spring morphotype). Averaged abundances from 20 subsamples are shown in Appendix A in site per season display of values. All benthic samples of macroinvertebrate fauna were collected with a kick-sampler $(200 \mu \mathrm{m}$ mesh size; from approximately $0.0625 \mathrm{~m}^{2}$ surface area) and preserved in alcohol. Adult water mite individuals were determined to species or genus level using [18-20], deutonymphs were determined using [21]. All water mite specimens are stored at Zoological collection of the Faculty of Science, Department of Biology in Zagreb, Croatia. 


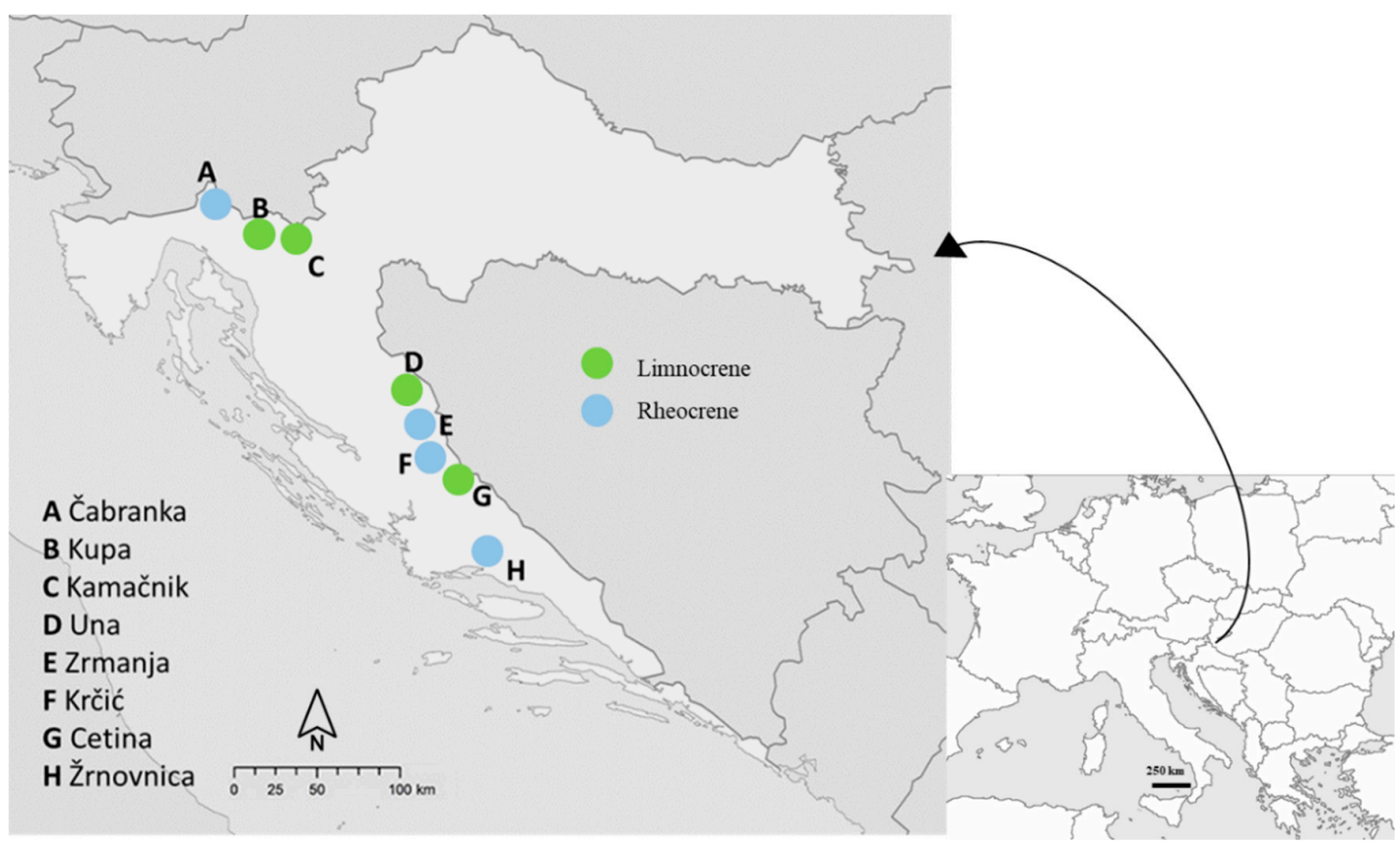

Figure 1. Map of the study area with the locations of the eight karst springs.

\subsection{Environmental Variables}

The following variables were chosen as environmental descriptors of differences between spring ecomorphotypes: water temperature, oxygen concentration and saturation (WTW optical oxygen sensor: FDO 925), chemical oxygen demand (COD; potassium permanganate oxidation by Standard Methods-APHA 2005), conductivity (WTW electrode conductivity measuring cell: TetraCon 925), concentration of calcium carbonate $\left(\mathrm{CaCO}_{3} \mathrm{mg} / \mathrm{L}\right)$ and discharge (data obtained from Croatian meteorological and hydrological service).

\subsection{Data Analysis}

Canonical correspondence analysis (CCA) was used to assess the response of limnocrene vs. rheocrene water mite assemblages, as well as specific water mite species to environmental water properties. Only water mite taxa determined to species level were included in the analysis. A Monte Carlo test using 999 permutations $(p<0.05)$ was performed to test the significance of the analysis using the CANOCO package v.5.0, Ithaca, NY, USA [22]. These analyses were done in order to determine possible differences in environmental parameters between limnocrenes and rheocrenes and their influence on water mite assemblage composition.

Water mite local diversity was assessed by calculating the Shannon diversity index in PRIMER v.6.0, Plymouth, UK [23]. The environmental variables, water mite species richness, abundance and local diversity were tested for significant differences between spring morphotypes using the Student's $t$-test. Prior to this testing, the data were tested for normal distribution using the Shapiro-Wilk's test. These analyses were done in Statistica, 13.0; Tulsa, OK, USA [24] in order to determine differences in environmental factors, and water mite species' richness, abundance and diversity indices between the two spring ecomorphotypes.

Water mite species were divided into two synecological groups: (1) crenophilous/crenobiont and (2) stygophilous taxa. The ecological preferences were determined using literature data from [18-20]. The differences in ratios of the synecological groups was tested between morphotypes using the Mann-Whitney U test in Statistica, 13.0 [24].

Water mite assemblages from rheocrenes represented Group 1 and from limocrenes represented Group 2 in the SIMPER analysis of the (Bray-Curtis) similarity between water mite assemblages. 
This was done in order to determine how water mite assemblages differ between ecomorphotypes in terms of species composition and abundance contribution. The analyses were done in PRIMER v.6.0 [23].

\section{Results}

A total of 20 water mite species was determined in this study, eight of which are recoded for the first time in Croatia: Atractides latipalpis, A. walteri, Lethaxona cavifrons, Ljania macilenta, Partnunia steinmanni, Sperchon hibernicus, S. thienemanni and S. vaginosus.

\subsection{Environmental Conditions in Spring Ecomorphotypes}

In the CCA analysis, the seven evaluated environmental parameters explained $33.6 \%$ of the total variation of water mite assemblages. The eigenvalues of the first two axes were 0.61 and 0.54 (Figure 2). A Monte-Carlo permutation test showed that the ordination was statistically significant $(\mathrm{F}=2.4$, $p=0.002$ ). Limnocrenes were, in general, associated with higher levels of oxygen concentration and discharge, whereas rheocrenes were associated with higher values in conductivity and dissolved calcium carbonate. Atractides pennatus and Partnunia angusta were positively associated with higher water temperatures, whereas Sperchon thienemanni was negatively associated to higher temperatures. Woolastookia rotundifrons was positively associated with higher discharge levels. Protzia squamousa was found to positively associate with sites of higher levels of dissolved calcium carbonate and conductivity. Partnunia steinmanni was found to negatively associate with sites of higher COD values. Other species were positioned centrally in the analysis, or (as is the case with species like Pseudotorrenticola rynchota and Sperchon vaginosus) had multiple factors positioning them away from the centre, but were not significantly linked to any.

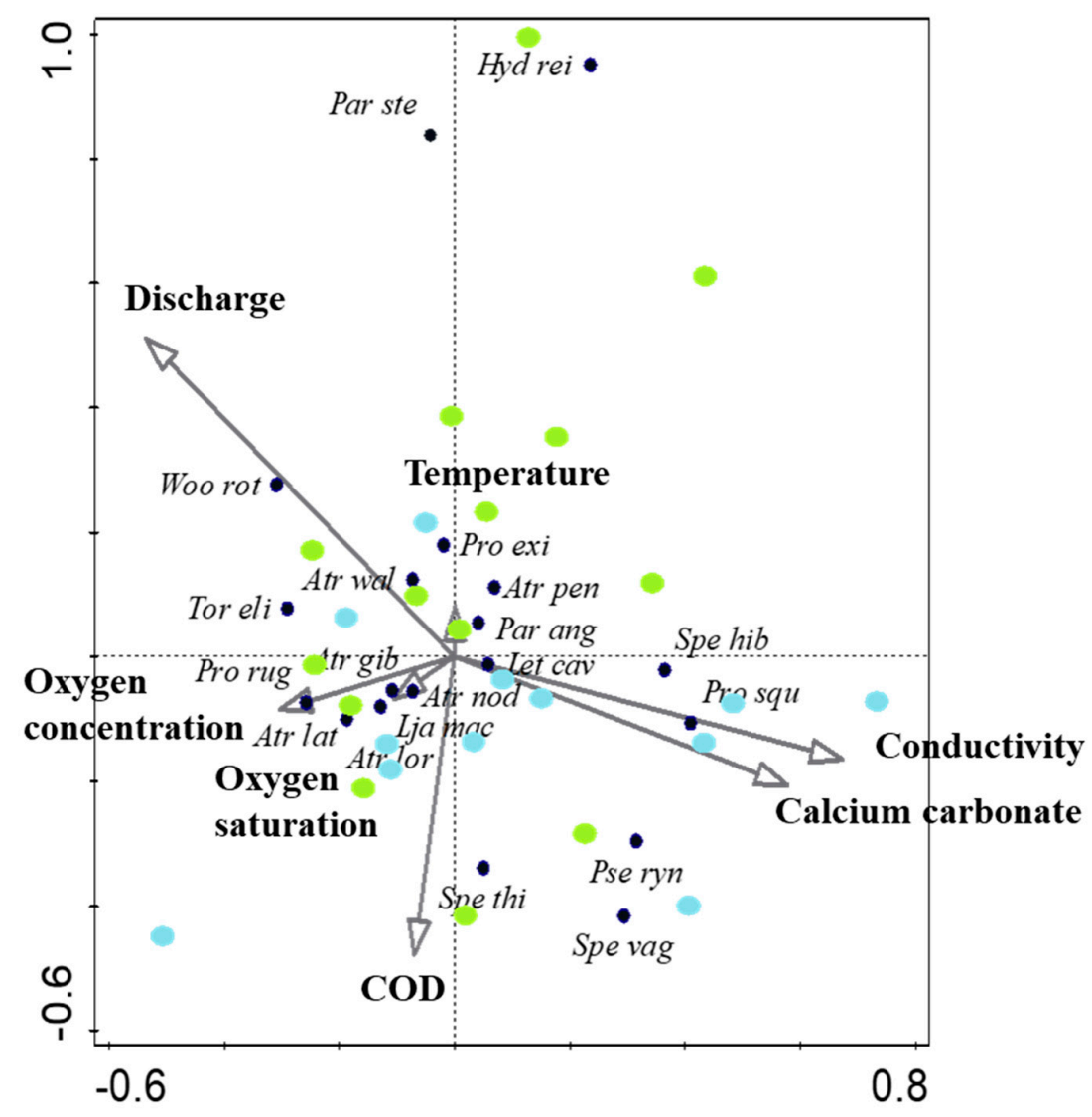

Figure 2. Canonical correspondence analysis (CCA) ordination of water mite samples, species and environmental water properties. Water mite taxa are marked with black dots, samples from limnocrenes 
with green dots, samples from rheocrenes with blue dots and environmental water properties with arrows. Arrow length on the ordination indicates the relative importance of the explanatory variables (physico-chemical water properties), and their direction relative to each other and to the sites indicates positive or negative correlations. Abbreviations: $\mathrm{COD}=\mathrm{Chemical}$ oxygen demand; Atractides gibberipalpis = Atr gib; A. latipalpis = Atr lat; A. loricatus = Atr lor; A. nodipalpis = Atr nod; $A$. pennatus = Atr pen; A. walteri = Atr wal; Hydrodroma reinhardi $=$ Hyd rei; Lethaxona cavifrons = Let cav; Ljania macilenta = Lja mac; Partnunia angusta = Par ang; Partnunia steinmanni = Par ste; Protzia eximia = Pro exi; Protzia squamosa = Pro squ; Protzia rugosa = Pro rug; Pseudotorrenticola rhynchota = Pse ryn; Sperchon hibernicus $=$ Spe hib; S. vaginosus $=$ Spe vag; S. thienemanni $=$ Spe thi; Torrenticola elliptica $=$ Tor eli; Woolastookia rotundifrons $=$ Woo rot.

Oxygen concentration values ( $t$-test, $\mathrm{F}=1.18 ; p<0.01)$ and discharge levels $(\mathrm{F}=7.52 ; p<0.001)$ were significantly higher in limnocrenes, whereas conductivity $(\mathrm{F}=3.26 ; p<0.05)$ and values of dissolved $\mathrm{CaCO}_{3}(\mathrm{~F}=5.14 ; p<0.01)$ were significantly higher in rheocrenes.

\subsection{Water Mite Diversity in Spring Morphotypes}

Water mite abundances were found not to differ significantly between spring morphotypes (Figure 3). However, water mite species richness ( $\mathrm{F}=1.517 ; p<0.05)$ and local diversity (Shannon index; $\mathrm{F}=1.257 ; p<0.05)$ were found to be significantly higher in rheocrenes when compared to limnocrenes.

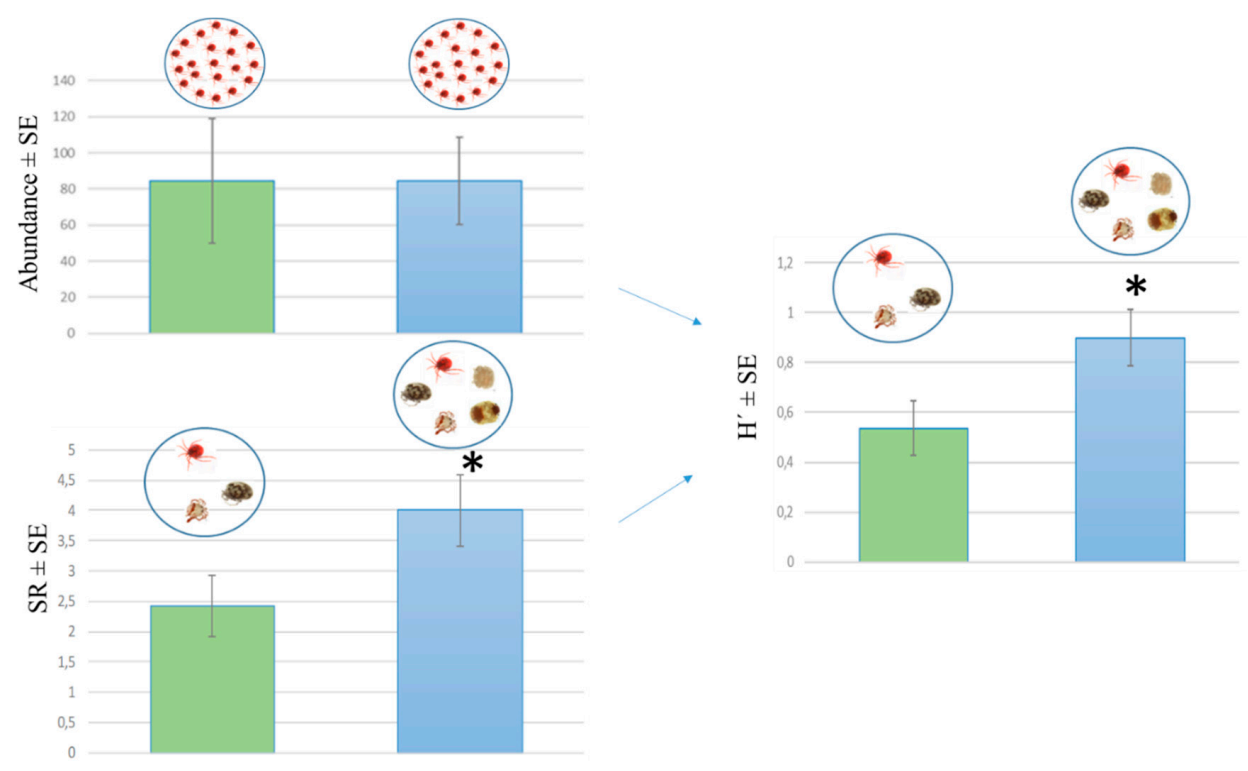

Figure 3. Illustration of the differences in water mite diversity (Shannon index, $\mathrm{H}^{\prime}$ ) between limnocrenes (with green bars) and rheocrenes (with blue bars) as a result of water mite abundance and species richness (SR). Columns represent average values, whereas error bars represent the calculated standard errors (SE). The asterisk * indicates statistically significant $(p<0.05)$ differences between spring morphotypes ( $t$-test).

Water mite species Atractides walteri, Hydrodroma reinhardi, Partnunia steinmanni, Sperchon vaginosus, S. thienemanni, Torrenticola elliptica and Woolastookia rotundifrons were found only in limnocrenes, whereas Atractides latipalpis, A. loricatus, Lethaxona cavifrons, Ljania macilenta, Partnunia angusta and Sperchon hibernicus were found exclusively in rheocrenes.

\subsection{Synecological Water Mite Groups in Spring Morphotypes}

Water mite species were divided into two synecological groups with regard to crenal and groundwater habitat preferences (Table 1). Two species, Partnunia angusta and Torrenticola elliptica, 
showed preferences to both habitat types. The ratio of crenophilous and crenobiont water mite taxa in the water mite assemblages varied greatly among sites, ranging from 0 to $100 \%$ of this synecological group within a local assemblage (details in appendix). The shares of stygophilous taxa ranged from 0 to $53 \%$ within a local assemblage. Stygophilous taxa, on average, made up around $4.4 \% \pm 13.2 \%$ of water mite assemblages in limnocrenes and around $5.7 \% \pm 11.1 \%$ in rheocrenes, but both ratios showed great variability, with standard deviations exceeding the average. The slightly higher ratios of stygophilous taxa in rheocrenes compared to limnocrenes were not statistically significant (Mann-Whitney $U$-test, $Z=0.73 ; p>0.05$ ). Crenobiont and crenophilous taxa, on average, made up around $19.6 \% \pm 28.5 \%$ of water mite assemblages in limnocrenes and around $15.6 \% \pm 27.7 \%$ in rheocrenes (again very high variability present shown in high standard deviations). The higher ratios of crenobiont and crenophilous taxa in limnocrenes compared to rheocrenes were statistically significant $(Z=2.85$; $p<0.05)$.

Table 1. List of water mite species with determined ecological preferences (synecological groups) to crenal and groundwater habitats. Ecological preferences were determined using literature data from [18-20].

\begin{tabular}{ccc}
\hline Water Mite Species & Preferences to Crenal Habitats & Preferences to Groundwater Habitats \\
\hline Atractides latipalpis & & Stygophilous \\
Atractides pennatus & Crenobiont & \\
Atractides walteri & Crenobiont & Stygophilous \\
Lethaxona cavifrons & & Stygophilous \\
Ljania macilenta & Crenophilous & Stygophilous \\
Partnunia angusta & Crenobiont & \\
Partnunia steinmanni & Crenophilous & \\
Protzia eximia & Crenobiont & Stygophilous \\
Protzia squamosa & Crenophilous & Stygophilous \\
Pseudotorrenticola rhynchota & Crenophilous & \\
Sperchon thienemanni & & \\
Torrenticola elliptica & &
\end{tabular}

\subsection{Water Mite Assemblage Similarity within Spring Morphotypes}

The SIMPER group similarity analysis (only portraying taxa that contributed $4 \%$ to group similarity or more, Table 2) showed that both groups of sites (Group R- Rheocrenes and Group L-Limnocrenes) had a relatively high presence of Atractides nodipalpis and A. gibberipalpis individuals. Protzia species: $P$. squamosa and P. rugosa were associated with rheocrene sites whereas; $A$. pennatus individuals were associated with limnocrenes. Juvenile instars (nymphs) of numerous taxa also contributed to the similarity within spring groups.

Table 2. Results of the SIMPER analysis based on water mite assemblages from sites of different spring morphology: R-Rheocrenes and L-Limnocrenes.

\begin{tabular}{ccc}
\hline Species & $\begin{array}{c}\text { Average Abundance } \\
\text { (Individuals/m } \mathbf{m}^{2} \text { ) }\end{array}$ & $\begin{array}{c}\text { Contribution to Group } \\
\text { Similarity (\%) }\end{array}$ \\
\hline Group R-Rheocrenes & & \\
Average similarity: 20.12 & & \\
Atractides gibberipalpis & 1.73 & 20.63 \\
Lebertia sp. & 1.07 & 20.31 \\
Atractides nodipalpis & 1.22 & 10.15 \\
Torrenticola sp. & 1.1 & 9.44 \\
Atractides sp. & 1.15 & 8.87 \\
Protzia squamosa & 1.02 & 6.28 \\
Sperchon sp. & 0.9 & 5.01 \\
Protzia rugosa & 0.68 & 4.05 \\
Group L-Limnocrenes & & \\
Average similarity: 19.44 & 1.77 & 34.46 \\
Sperchon sp. & 1.21 & 27.98 \\
Atractides sp. & 0.82 & 7.31 \\
Atractides nodipalpis & 0.9 & 5.23 \\
Atractides gibberipalpis & 0.46 & 4.21 \\
Atractides pennatus & & \\
\hline
\end{tabular}




\section{Discussion}

Significant correlations with water temperature were determined for three water mite species, interestingly, all determined as crenobiont species. However, these significant relationships were not all showing the same trends. A. pennatus and P. angusta showed positive associations to higher water temperature, whereas $S$. thienemanni had the opposite trend. The idea that crenobiont species are cold stenothermic is questioned once more, and perhaps a more suitable angle of the problem, as proposed by Gerecke et al. [11], would suggest that the crenobiont water mite species are, in fact, "warm stenothermic". [11] proposed that such a vast speciation rate of crenal water mites might be due to the mild and stable environmental conditions in springs that are most obvious and pronounced in winter, thus taking the cold stenothermal theory and turning it upside-down. However, the constant temperature alone is most certainly not the only factor that contributes to the water mite diversity in springs, as crenobiont species are even found in tropical regions, where the temperature remains unchanged between the crenal area and lower river reaches $[25,26]$. The temperature arrow length in the CCA (indicates the relative importance of explanatory variable) was by far the smallest in the analysis (Figure 2). This is surely a result of the narrow temperature gradient present in springs, but also may indicate that, in fact, this factor is not the driving force of water mite diversity in springs. In this study, the environmental variables explained a substantial $33 \%$ of the total water mite variability in the studied springs, indicating that abiotic conditions are undoubtedly important contributors to water mite diversity. However, a more detailed portrait of the environmental effects would perhaps be shown if nutrient content in waters and available food sources were analyzed as well, but this was not the main focus of this paper. Here, a much broader approach regarding the influence of environmental conditions was taken when morphotypes were examined as the key drivers of water mite diversity in springs included in this research (as ecomorphotypes are hypothesized as one of the main drivers of environmental conditions within springs). A whole set of environmental variables (oxygen concentration, discharge levels, conductivity and dissolved $\mathrm{CaCO}_{3}$ ) were found to significantly differ between ecomorphotypes, thus validating the approach.

Higher species richness and local diversity were recorded in rheocrenes when compared to limnocrenes, as expected when it comes to springs in Europe.

The differences between stygophilous water mite taxa ratios among spring ecomorphotypes were not statistically significant, indicating that the degree of the ground water/surface water interaction (and water mite interaction therein) does not seem to be directly influenced by spring ecomorphotype. Nevertheless, it is important to note that several/some stygophilous species-A. latipapis, L. cavifrons, L. macilenta and P. angusta-were found exclusively in rheocrenes.

Species that were exclusively found in limnocrenes fall into very different categories when it comes to habitat preferences: crenobiont (A. walteri, P. steinmanni), crenophilous (S. thienemanni, T. elliptica) to rheophilous species (H. reinhardi, S. vaginosus, W. rotundifrons). Species A. walteri and $P$. steinmanni, although crenobionts, are not considered highly specialized when it comes to spring ecomorphotype and environmental conditions. S. thienemanni is considered as one of the most widespread and abundant crenophilous taxa, and also as non-specific when it comes to ecomorphotype [27]. The distribution of many species in a large karstic limnocrenes (such as the ones discussed in this paper) depends on microhabitat/substrate composition, which provides conditions for different synecological groups; for example, the deeper part of limnocrenes provides conditions for good swimmers, while the spring brooks, often characterized by gravel/sandy substrate, can provide a habitat for crawlers such as T. elliptica and W. rotundifrons, which are usually associated with more riffle type habitats. A. latipalpis (stygophilous), A. loricatus (rheophilous), L. cavifrons (stygophilous), L. macilenta (stygophilous), P. angusta (crenophilous/stygophilous) and S. hibernicus (rheophilous) were found exclusively in rheocrenes. 


\section{Conclusions}

With all the aforementioned taxa found exclusively in one spring ecomorphotype making up for more than $50 \%$ of the total taxa found in this research, we can conclude that spring ecomorphotype is indeed a crucial driver of water mite diversity. Furthermore, within this research, $40 \%$ of identified water mite species (eight out of twenty) were recorded for the first time in Croatia [28] (and quotes therein), thus highlighting once more the vast and undisclosed water mite diversity in spring ecosystems as well as the importance of spring habitats for the overall regional diversity of water mites. There is no ecology without knowing the fundamentals—species richness and diversity—and this is especially true in the case of research on one of the most diverse group of animals-water mites-in some of the most fragile ecosystems-freshwater springs.

Author Contributions: Conceptualization and supervision, I.P. and S.G.; methodology, S.G. and I.P.; formal analysis, I.P., S.G., T.G. and V.P.; resources, S.G. and I.P.; data curation, I.P., S.G, T.G. and V.P.; visualization, I.P.; funding acquisition, S.G.; project administration, S.G.; writing—original draft preparation, I.P.; writing-review and editing, I.P., S.G., T.G. and V.P. All authors have read and agreed to the published version of the manuscript.

Funding: This research was funded by The Environmental Protection and Energy Efficiency Fund (EPEEF) of Croatia, as part of the MULTISEC project (MULTImetric System of Evaluating Crenobiocoenosis) study conducted from September 2013 to December 2016. Project manager: Sanja Gottstein.

Acknowledgments: We kindly thank Ivica Barač for assistance in filed work.

Conflicts of Interest: The authors declare no conflict of interest.

\section{Appendix A}

Table A1. Seasonal values of measured environmental variables in the studied limnocrenes and rheocrenes. ( $\mathrm{T}=$ water temperature, con. $\mathrm{O}_{2}=$ oxygen concentration, sat. $\mathrm{O}_{2}=$ oxygen saturation, $\sigma=$ conductivity, $\mathrm{CaCO}_{3}=$ calcium carbonate concentration, $\mathrm{COD}=$ chemical oxygen demand).

\begin{tabular}{|c|c|c|c|c|c|c|c|}
\hline $\begin{array}{c}\text { Spring } \\
\text { (Morphotype) }\end{array}$ & Season & $\mathrm{T}\left({ }^{\circ} \mathrm{C}\right)$ & $\begin{array}{c}\text { Con. } \mathrm{O}_{2} \\
(\mathrm{mg} / \mathrm{L})\end{array}$ & $\begin{array}{c}\text { Sat. } \mathrm{O}_{2} \\
(\%)\end{array}$ & $\sigma(\mu \mathrm{S} / \mathrm{cm})$ & $\begin{array}{l}\mathrm{CaCO}_{3} \\
(\mathrm{mg} / \mathrm{L})\end{array}$ & $\begin{array}{c}\mathrm{COD} \\
\left(\mathrm{mgO}_{2} / \mathrm{L}\right)\end{array}$ \\
\hline \multirow{4}{*}{$\begin{array}{l}\text { Čabranka } \\
\text { (Rheocrene) }\end{array}$} & Fall & 8.75 & 11.39 & 105.73 & 436.00 & 232.50 & 2.01 \\
\hline & Summer & 8.80 & 11.12 & 101.60 & 420.33 & 206.67 & 0.68 \\
\hline & Spring & 8.67 & 13.08 & 119.50 & 409.67 & 205.83 & 0.93 \\
\hline & Winter & 8.38 & 11.09 & 101.50 & 378.75 & 192.50 & 1.81 \\
\hline \multirow{4}{*}{$\begin{array}{c}\text { Cetina } \\
\text { (Limnocrene) }\end{array}$} & Fall & 8.40 & 12.25 & 104.80 & 331.00 & 160.00 & 1.18 \\
\hline & Summer & 9.10 & 13.02 & 114.83 & 294.00 & 145.00 & 1.10 \\
\hline & Spring & 8.90 & 14.16 & 128.13 & 310.00 & 165.00 & 0.83 \\
\hline & Winter & 8.90 & 12.81 & 111.38 & 338.00 & 175.00 & 0.24 \\
\hline \multirow{4}{*}{$\begin{array}{c}\text { Kamačnik } \\
\text { (Limnocrene) }\end{array}$} & Fall & 7.40 & 11.74 & 102.10 & 336.00 & 180.00 & 2.36 \\
\hline & Summer & 9.23 & 12.57 & 114.70 & 303.25 & 166.25 & 0.58 \\
\hline & Spring & 9.30 & 12.30 & 111.13 & 296.00 & 138.75 & 0.63 \\
\hline & Winter & 7.20 & 11.95 & 103.70 & 322.00 & 162.50 & 1.02 \\
\hline \multirow{4}{*}{$\begin{array}{c}\text { Krčić } \\
\text { (Rheocrene) }\end{array}$} & Fall & 9.10 & 10.29 & 97.25 & 395.00 & 200.00 & 1.49 \\
\hline & Summer & 9.70 & 10.63 & 101.43 & 395.00 & 202.50 & 0.94 \\
\hline & Spring & 9.00 & 10.03 & 95.68 & 323.00 & 165.00 & 1.34 \\
\hline & Winter & 8.90 & 9.90 & 94.30 & 406.00 & 195.00 & 1.49 \\
\hline \multirow{4}{*}{$\begin{array}{c}\text { Kupa } \\
\text { (Limnocrene) }\end{array}$} & Fall & 7.73 & 10.73 & 96.10 & 283.25 & 153.13 & 1.79 \\
\hline & Summer & 9.40 & 11.50 & 103.00 & 266.75 & 135.63 & 0.85 \\
\hline & Spring & 8.40 & 10.78 & 97.90 & 236.00 & 124.17 & 0.89 \\
\hline & Winter & 7.57 & 11.49 & 103.80 & 256.33 & 125.83 & 1.55 \\
\hline \multirow{4}{*}{$\begin{array}{c}\text { Una } \\
\text { (Limnocrene) }\end{array}$} & Fall & 9.50 & 11.80 & 104.20 & 414.00 & 227.50 & 1.57 \\
\hline & Summer & 11.80 & 11.72 & 102.70 & 420.00 & 215.00 & 1.18 \\
\hline & Spring & 10.20 & 11.33 & 104.10 & 394.00 & 205.00 & 0.71 \\
\hline & Winter & 9.30 & 11.35 & 101.10 & 440.00 & 247.50 & 1.41 \\
\hline \multirow{4}{*}{$\begin{array}{c}\text { Zrmanja } \\
\text { (Rheocrene) }\end{array}$} & Fall & 8.90 & 10.50 & 95.30 & 359.00 & 195.00 & 1.34 \\
\hline & Summer & 9.80 & 11.84 & 108.70 & 347.00 & 170.00 & 1.10 \\
\hline & Spring & 9.50 & 10.85 & 98.90 & 319.00 & 175.00 & 1.81 \\
\hline & Winter & 8.40 & 12.08 & 107.50 & 363.00 & 185.00 & 1.81 \\
\hline \multirow{4}{*}{$\begin{array}{l}\text { Žrnovnica } \\
\text { (Rheocrene) }\end{array}$} & Fall & 12.52 & 11.26 & 102.30 & 413.80 & 190.00 & 1.20 \\
\hline & Summer & 12.60 & 11.63 & 106.80 & 393.00 & 185.83 & 1.26 \\
\hline & Spring & 12.56 & 11.14 & 107.90 & 369.57 & 185.00 & 0.79 \\
\hline & Winter & 12.50 & 11.37 & 103.40 & 373.33 & 189.17 & 1.09 \\
\hline
\end{tabular}


Table A2. Seasonal microhabitat ratios in the studied limnocrenes and rheocrenes.

\begin{tabular}{|c|c|c|c|c|c|c|}
\hline \multirow{2}{*}{ Spring } & \multirow{2}{*}{ Latitude } & \multirow{2}{*}{ Longitude } & \multicolumn{4}{|c|}{ Microhabitat Ratio (\%) } \\
\hline & & & Spring & Summer & Fall & Winter \\
\hline $\begin{array}{l}\text { Čabranka } \\
\text { (Rheocrene) }\end{array}$ & $45^{\circ} 36^{\prime} 02.6^{\prime \prime}$ & $14^{\circ} 38^{\prime} 27.3^{\prime \prime}$ & $\begin{array}{l}\text { Microlithal + Mesolithal }(40 \%) \\
\text { Phytal }(60 \%)\end{array}$ & $\begin{array}{l}\text { Microlithal + Mesolithal }(60 \%) \\
\text { Phytal }(40 \%)\end{array}$ & $\begin{array}{l}\text { Microlithal + Mesolithal (55\%), } \\
\text { Phytal (45\%) }\end{array}$ & Mesolithal (70\%), Phytal (30\%) \\
\hline $\begin{array}{c}\text { Cetina } \\
\text { (Limnocrene) }\end{array}$ & $43^{\circ} 58^{\prime} 50.9^{\prime \prime}$ & $16^{\circ} 25^{\prime} 81.4^{\prime \prime}$ & $\begin{array}{l}\text { Akal (15\%), Macrolithal (50\%), } \\
\text { Phytal (35\%) }\end{array}$ & $\begin{array}{c}\text { Microlithal + Mesolithal + } \\
\text { Macrolithal (30\%), Phytal } \\
(30 \%) \text {, Psammal }(40 \%)\end{array}$ & $\begin{array}{c}\text { Akal (15\%), Mesolithal (45\%), } \\
\text { Phytal (40\%) }\end{array}$ & $\begin{array}{c}\text { Microlithal + Mesolithal }(55 \%) \\
\text { Phytal }(45 \%)\end{array}$ \\
\hline $\begin{array}{l}\text { Kamačnik } \\
\text { (Limnocrene) }\end{array}$ & $45^{\circ} 20^{\prime} 49.3^{\prime \prime}$ & $15^{\circ} 03^{\prime} 38^{\prime \prime}$ & $\begin{array}{c}\text { Ksilal + Microlithal + } \\
\text { Mesolithal (40\%), Phytal }(60 \%)\end{array}$ & $\begin{array}{c}\text { Macrolithal + Megalithal }(10 \%), \\
\text { Phytal }(90 \%)\end{array}$ & Microlithal (10\%), Phytal (90\%) & $\begin{array}{l}\text { Microlithal + Mesolithal }(10 \%) \\
\text { Phytal }(90 \%)\end{array}$ \\
\hline $\begin{array}{c}\text { Krčić } \\
\text { (Rheocrene) }\end{array}$ & $44^{\circ} 25^{\prime} 48^{\prime \prime}$ & $16^{\circ} 33^{\prime} 61.9^{\prime \prime}$ & Phytal $(100 \%)$ & Mesolithal (40\%), Phytal (60\%) & Mesolithal (20\%), Phytal (80\%) & Phytal (100\%) \\
\hline $\begin{array}{c}\text { Kupa } \\
\text { (Limnocrene) }\end{array}$ & $45^{\circ} 29^{\prime} 27.2^{\prime \prime}$ & $14^{\circ} 41^{\prime} 28.5^{\prime \prime}$ & $\begin{array}{c}\text { Megalithal (15\%), Mesolithal + } \\
\text { Macrolithal (30\%), Phytal (50\%) } \\
\text { Psammal (5\%) }\end{array}$ & $\begin{array}{l}\text { Microlithal (20\%), Mesolithal } \\
\quad(40 \%) \text {, Phytal (40\%) }\end{array}$ & $\begin{array}{l}\text { Microlithal + Mesolithal (80\%), } \\
\text { Phytal (10\%), Psammal (10\%) }\end{array}$ & Phytal (50\%), Mesolithal (50\%) \\
\hline $\begin{array}{c}\text { Una } \\
\text { (Limnocrene) }\end{array}$ & $44^{\circ} 24^{\prime} 12.9^{\prime \prime}$ & $16^{\circ} 06^{\prime} 41.6^{\prime \prime}$ & Phytal (100 \%) & $\begin{array}{c}\text { Akal + Microlithal (10\%), } \\
\text { Mesolithal + Macrolithal (20\%), } \\
\text { Phytal (70\%) }\end{array}$ & $\begin{array}{c}\text { Microlithal + Mesolithal }(80 \%) \\
\text { Phytal }(20 \%)\end{array}$ & $\begin{array}{c}\text { Akal + Mesolithal (30\%), } \\
\text { Macrolithal + Mesolithal (50\%), } \\
\text { Phytal (20\%) }\end{array}$ \\
\hline $\begin{array}{c}\text { Zrmanja } \\
\text { (Rheocrene) }\end{array}$ & $44^{\circ} 11^{\prime} 79.2^{\prime \prime}$ & $16^{\circ} 03^{\prime} 38.1^{\prime \prime}$ & $\begin{array}{c}\text { Microlithal + Mesolithal + } \\
\text { Microlithal (55\%), Phytal (45\%) }\end{array}$ & $\begin{array}{c}\text { Microlithal + Mesolithal (50\%), } \\
\text { Phytal (50\%) }\end{array}$ & $\begin{array}{c}\text { Microlithal + Mesolithal }(40 \%) \\
\text { Phytal }(60 \%)\end{array}$ & $\begin{array}{c}\text { Akal + Microlithal + } \\
\text { Mesolithal (40\%), Phytal (60\%) }\end{array}$ \\
\hline $\begin{array}{l}\text { Žrnovnica } \\
\text { (Rheocrene) }\end{array}$ & $43^{\circ} 31^{\prime} 24.8^{\prime \prime}$ & $16^{\circ} 34^{\prime} 29.2^{\prime \prime}$ & $\begin{array}{c}\text { Mesolithal + Megalithal }(60 \%) \text {, } \\
\text { Phytal }(40 \%)\end{array}$ & $\begin{array}{c}\text { Microlithal + Mesolithal (30\%), } \\
\text { Phytal (70\%) }\end{array}$ & $\begin{array}{c}\text { Microlithal + Mesolithal }(40 \%) \\
\text { Phytal }(60 \%)\end{array}$ & Phytal $(100 \%)$ \\
\hline
\end{tabular}

Table A3. Seasonal water mite taxa occurrence in the studied limnocrenes and rheocrenes.

\begin{tabular}{|c|c|c|c|c|c|c|c|c|c|c|c|c|c|c|c|}
\hline Spring & Season & $\begin{array}{c}\text { Atractides } \\
\text { Sp. }\end{array}$ & $\begin{array}{l}\text { Atractides } \\
\text { Gibberipapis }\end{array}$ & $\begin{array}{l}\text { Atractides } \\
\text { Latipapis }\end{array}$ & $\begin{array}{l}\text { Atractides } \\
\text { Loricatus }\end{array}$ & $\begin{array}{l}\text { Atractides } \\
\text { Nodipapis }\end{array}$ & $\begin{array}{c}\text { Atractides } \\
\text { Penatus }\end{array}$ & $\begin{array}{c}\text { Atractides } \\
\text { Walteri }\end{array}$ & Aturus Sp. & Feltria Sp. & $\begin{array}{l}\text { Hydrodroma } \\
\text { Reinhardii }\end{array}$ & $\begin{array}{l}\text { Lebertia } \\
\text { Sp. }\end{array}$ & $\begin{array}{l}\text { Lethaxona } \\
\text { Cavifrons }\end{array}$ & $\begin{array}{c}\text { Ljania } \\
\text { Macilenta }\end{array}$ & $\begin{array}{c}\text { Partnunio } \\
\text { Angusta }\end{array}$ \\
\hline $\begin{array}{l}\text { Čabranka } \\
\text { (Rheocrene) }\end{array}$ & $\begin{array}{l}\text { Fall } \\
\text { Summer } \\
\text { Spring }\end{array}$ & & & & & & & & & & + & & & & \\
\hline & Winter & & & & & & & & & & + & & & & \\
\hline Cetina & Fall & & + & & & & & & + & + & & + & & & \\
\hline (Limnocrene) & Summer & & + & & & + & & & & & & + & & & \\
\hline & Spring & + & & & & + & & & & & & + & & & + \\
\hline & Winter & + & & & & & & & & & & + & & & \\
\hline $\begin{array}{l}\text { Kamačnik } \\
\text { (Limnocrene) }\end{array}$ & $\begin{array}{l}\text { Fall } \\
\text { Summer }\end{array}$ & & & & & & + & & & & & & & & \\
\hline & Spring & + & & & & & & & & + & & & & & \\
\hline Krčić & $\begin{array}{c}\text { Winter } \\
\text { Fall }\end{array}$ & + & & & & & + & & & & & & & & \\
\hline (Rheocrene) & $\begin{array}{l}\text { Summer } \\
\text { Spring } \\
\text { Winter }\end{array}$ & + & & & & & & & & & & + & & & \\
\hline
\end{tabular}


Table A3. Cont.

\begin{tabular}{|c|c|c|c|c|c|c|c|c|c|c|c|c|c|c|c|}
\hline Kupa & Fall & + & + & & & & & & & & & & & & \\
\hline \multirow{3}{*}{ (Limnocrene) } & Summer & + & + & & & + & & & + & + & & + & & & \\
\hline & Spring & + & + & & & + & & & + & + & & + & & & \\
\hline & Winter & + & + & & & + & & & + & + & & + & & & \\
\hline \multirow{3}{*}{$\begin{array}{c}\text { Una } \\
\text { (Limnocrene) }\end{array}$} & Fall & + & + & & & + & & + & + & & & & & & \\
\hline & Summer & & & & & & + & & + & & & + & & & \\
\hline & $\begin{array}{l}\text { Spring } \\
\text { Winter }\end{array}$ & & & & & + & + & & + & & & & & & \\
\hline \multirow{3}{*}{$\begin{array}{c}\text { Zrmanja } \\
\text { (Rheocrene) }\end{array}$} & Fall & + & + & + & + & + & & & + & + & & + & & + & \\
\hline & Summer & + & + & & & + & & & + & + & & + & + & + & \\
\hline & $\begin{array}{l}\text { Spring } \\
\text { Winter }\end{array}$ & + & + & & & $\begin{array}{l}+ \\
+\end{array}$ & & & + & & & & & & \\
\hline \multirow{4}{*}{$\begin{array}{l}\text { Žrnovnica } \\
\text { (Rheocrene) }\end{array}$} & Fall & $T$ & & & & & + & & . & & & + & & & \\
\hline & Summer & & + & & & & & & & & & & & & + \\
\hline & Spring & & + & & & & & & & & & & & & + \\
\hline & Winter & & & & & & + & & & & & & & & + \\
\hline Spring & Season & $\begin{array}{l}\text { Partnunia } \\
\text { Steinmani }\end{array}$ & $\begin{array}{l}\text { Protzia } \\
\text { Eximia }\end{array}$ & $\begin{array}{c}\text { Protzia } \\
\text { Squamosa }\end{array}$ & $\begin{array}{l}\text { Protzia } \\
\text { Rugosa }\end{array}$ & $\begin{array}{l}\text { Pseudotorrent-Icola } \\
\text { Rhynchota }\end{array}$ & $\begin{array}{l}\text { Sperchon } \\
\text { Hibernicus }\end{array}$ & $\begin{array}{l}\text { Sperchon } \\
\text { Deticulatus } \\
\text { Group }\end{array}$ & $\begin{array}{l}\text { Sperchon } \\
\text { Vaginousus }\end{array}$ & $\begin{array}{l}\text { Sperchon } \\
\text { Sp. }\end{array}$ & $\begin{array}{l}\text { Sperchon } \\
\text { Thienemanni }\end{array}$ & $\begin{array}{l}\text { Torrenticola } \\
\text { Eliptica }\end{array}$ & $\begin{array}{l}\text { Torrenticola } \\
\text { Sp. }\end{array}$ & $\begin{array}{l}\text { Woolastookia } \\
\text { Rotundifrons }\end{array}$ & $\begin{array}{l}\text { Hydrachnidia } \\
\text { (Larvae) }\end{array}$ \\
\hline \multirow[t]{2}{*}{$\begin{array}{l}\text { Čabranka } \\
\text { (Rheocrene) }\end{array}$} & $\begin{array}{l}\text { Fall } \\
\text { Summer } \\
\text { Spring }\end{array}$ & + & & & & & & & & & & & & & \\
\hline & Winter & + & & & & & & & & & & & & & \\
\hline \multirow{4}{*}{$\begin{array}{c}\text { Cetina } \\
\text { (Limnocrene) }\end{array}$} & Fall & & & + & & + & & & + & & & & + & & \\
\hline & Summer & & & + & & & & + & & & & & + & & \\
\hline & Spring & & & + & & + & + & + & & & & & + & & + \\
\hline & Winter & & & + & & & & + & & & & & + & & \\
\hline \multirow{4}{*}{$\begin{array}{l}\text { Kamačnik } \\
\text { (Limnocrene) }\end{array}$} & Fall & & & & & & & & & & + & & & & \\
\hline & Summer & & & & & & & & & & & & & & \\
\hline & Spring & & & & & & & + & & & & & & & \\
\hline & Winter & & & & & & & & & + & + & & & & \\
\hline \multirow{3}{*}{$\begin{array}{c}\text { Krčić } \\
\text { (Rheocrene) }\end{array}$} & Fall & & & & & & & & & & & & & & \\
\hline & $\begin{array}{l}\text { Summer } \\
\text { Spring } \\
\text { Winter }\end{array}$ & & & & & & & & & & & & & & + \\
\hline & $\begin{array}{l}\text { Winter } \\
\text { Fall }\end{array}$ & + & & & & & & & & + & & & & & \\
\hline \multirow{3}{*}{ (Limnocrene) } & Summer & $t^{+}$ & & & + & & & & & $\begin{array}{l}+ \\
+\end{array}$ & & + & + & & + \\
\hline & Spring & & & & + & & & & & + & & + & + & & + \\
\hline & Winter & & & & + & & & & & + & & + & + & + & + \\
\hline \multirow{4}{*}{$\begin{array}{c}\text { Una } \\
\text { (Limnocrene) }\end{array}$} & Fall & & + & & & & & & & + & & & + & & \\
\hline & Summer & & + & & & & & & & + & & & & & + \\
\hline & Spring & & + & & & & & & & + & & & & & \\
\hline & Winter & & & & & & & & & & & & & & + \\
\hline \multirow{4}{*}{$\begin{array}{l}\text { Zrmanja } \\
\text { (Rheocrene) }\end{array}$} & Fall & & & & + & & & & & + & & & + & & + \\
\hline & Summer & & & & + & & & & & + & & & + & & + \\
\hline & Spring & & & & + & & & & & + & & & & & \\
\hline & Winter & & & & + & & & & & + & & & + & & + \\
\hline \multirow{3}{*}{$\begin{array}{l}\text { Žrnovnica } \\
\text { (Rheocrene) }\end{array}$} & Fall & & & & & & & & & & & & & & \\
\hline & Summer & & & & & & & & & + & & & + & & + \\
\hline & $\begin{array}{l}\text { Spring } \\
\text { Winter }\end{array}$ & & & & & & & & & & & & & & \\
\hline
\end{tabular}


Table A4. Seasonal water mite taxa richness, abundance, Shannon diversity values and ratios of synecological (*** indicates no water mites present, whereas $0 \%$ indicates no taxa from synecological group present) water mite groups in the studied limnocrenes and rheocrenes.

\begin{tabular}{|c|c|c|c|c|c|c|}
\hline $\begin{array}{c}\text { Spring } \\
\text { (Morphotype) }\end{array}$ & Season & Taxa Richness & $\begin{array}{c}\text { Abundance } \\
\text { (Individuals } / \mathbf{m}^{2} \text { ) }\end{array}$ & $\begin{array}{l}\text { Shannon Diversity } \\
\text { Index Value }\end{array}$ & $\begin{array}{c}\text { Ratio of } \\
\text { Stygophilous Taxa }\end{array}$ & $\begin{array}{l}\text { Ratio of Crenobiont and } \\
\text { Crenophilous Taxa }\end{array}$ \\
\hline Čabranka & Fall & 9 & 1280 & 1.446 & $1.82 \%$ & $7.27 \%$ \\
\hline \multirow[t]{3}{*}{ (Rheocrene) } & Summer & 7 & 309 & 1.459 & $0.00 \%$ & $37.50 \%$ \\
\hline & Spring & 9 & 451 & 1.447 & $5.92 \%$ & $56.21 \%$ \\
\hline & Winter & 5 & 53 & 1.359 & $0.00 \%$ & $79.17 \%$ \\
\hline & Fall & 2 & 57 & 0.693 & $0.00 \%$ & $0.00 \%$ \\
\hline \multirow{3}{*}{ (Limnocrene) } & Summer & 2 & 8 & 0.693 & $0.00 \%$ & $100.00 \%$ \\
\hline & Spring & 0 & 0 & 0 & $* * *$ & $* * *$ \\
\hline & Winter & 3 & 90 & 0.822 & $0.00 \%$ & $92.86 \%$ \\
\hline Kamačnik & Fall & 3 & 7 & 1 & $0.00 \%$ & $100.00 \%$ \\
\hline \multirow[t]{3}{*}{ (Limnocrene) } & Summer & 0 & 0 & 0 & $* * *$ & $* * *$ \\
\hline & Spring & 3 & 144 & 0.958 & $0.00 \%$ & $0.00 \%$ \\
\hline & Winter & 5 & 43 & 1.355 & $0.00 \%$ & $45.83 \%$ \\
\hline Krčić & Fall & 0 & 0 & 0 & $* * *$ & $* * *$ \\
\hline \multirow{3}{*}{ (Rheocrene) } & Summer & 3 & 32 & 0.856 & $0.00 \%$ & $0.00 \%$ \\
\hline & Spring & 0 & 0 & 0 & $* * *$ & $* * *$ \\
\hline & Winter & 0 & 0 & 0 & $* * *$ & $* * *$ \\
\hline Kupa & Fall & 4 & 14 & 1.091 & $0.00 \%$ & $14.29 \%$ \\
\hline \multirow{3}{*}{ (Limnocrene) } & Summer & 8 & 220 & 1.528 & $7.27 \%$ & $7.27 \%$ \\
\hline & Spring & 10 & 1667 & 1.583 & $44.44 \%$ & $44.44 \%$ \\
\hline & Winter & 12 & 856 & 1.479 & $53.08 \%$ & $53.08 \%$ \\
\hline \multirow{4}{*}{$\begin{array}{c}\text { Una } \\
\text { (Limnocrene) }\end{array}$} & Fall & 8 & 360 & 1.485 & $0.00 \%$ & $27.27 \%$ \\
\hline & Summer & 5 & 162 & 1.044 & $0.00 \%$ & $76.54 \%$ \\
\hline & Spring & 5 & 22 & 1.221 & $0.00 \%$ & $35.71 \%$ \\
\hline & Winter & 2 & 32 & 0.693 & $0.00 \%$ & $0.00 \%$ \\
\hline \multirow{4}{*}{$\begin{array}{l}\text { Zrmanja } \\
\text { (Rheocrene) }\end{array}$} & Fall & 13 & 900 & 1.711 & $13.39 \%$ & $0.00 \%$ \\
\hline & Summer & 11 & 630 & 1.552 & $1.52 \%$ & $0.00 \%$ \\
\hline & Spring & 4 & 9 & 1.242 & $0.00 \%$ & $0.00 \%$ \\
\hline & Winter & 8 & 288 & 1.444 & $0.00 \%$ & $0.00 \%$ \\
\hline \multirow{4}{*}{$\begin{array}{l}\text { Žrnovnica } \\
\text { (Rheocrene) }\end{array}$} & Fall & 3 & 5 & 1.04 & $0.00 \%$ & $50.00 \%$ \\
\hline & Summer & 5 & 25 & 1.274 & $36.36 \%$ & $36.36 \%$ \\
\hline & Spring & 3 & 12 & 1.011 & $33.33 \%$ & $33.33 \%$ \\
\hline & Winter & 3 & 35 & 0.986 & $27.27 \%$ & $100.00 \%$ \\
\hline
\end{tabular}




\section{References}

1. Gerecke, R.; Meisch, C.; Stoch, F.; Acri, F.; Franz, H. Eucrenon-hypocrenon ecotone and spring typology in the Alps of Berchtesgaden (Upper Bavaria, Germany). A study of microcrustacea (Crustacea: Copepoda, Ostracoda) and water mites (Acari: Halacaridae, Hydrachnellae). In Studies in Crenobiology; The Biology of Springs and Springbrooks; Botosaneanu, L., Ed.; Backhuys Publisher: Leiden, The Netherlands, 1998; pp. 167-182.

2. Knight, R.L.; Notestein, S.K. Effects of nutrients on spring ecosystems. In Summary and Synthesis of the Available Literature on the Effects of Nutrients on Spring Organisms and Systems; Florida Department of Environmental Protection: Tallahassee, FL, USA, 2008; pp. 271-304.

3. Stoch, F.; Gerecke, R.; Pieri, V.; Rossetti, G.; Sambugar, B. Exploring species distribution of spring meiofauna (Annelida, Acari, Crustacea) in the south-eastern Alps. J. Limnol. 2011, 70 (Suppl. 1), 65-76. [CrossRef]

4. Reiss, M.; Chifflard, P. Hydromorphology and Biodiversity in headwaters: An Eco-faunistic substrate preference assessment in forest springs of the German subdued mountains. In Biodiversity in Ecosystems-Linking Structure and Function; Lo, Y.-H., Blanco, J.A., Roy, S., Eds.; InTech Open: Rijeka, Croatia, 2015; pp. 223-258.

5. Gottstein, M.S.; Bakran-Petricioli, T.; Bedek, J.; Bukovec, D.; Buzjak, S.; Franičević, M.; Tvrtković, N. An overview of the cave and interstitial biota in Croatia. Nat. Croat. 2002, 11 (Suppl. 1), 1-112.

6. Bonacci, O. Karst springs hydrographs as indicators of karst aquifers. Hydrol. Sci. J. 1993, 38, 51-62. [CrossRef]

7. Smart, C.; Worthington, S.R.H. Springs. In Encyclopedia of Caves and Karst Science; Gunn, J., Ed.; Taylor \& Francis: London, UK, 2004; pp. 1495-1505.

8. Prelovšek, M. Hydrology. In Introduction to the Dinaric Karst; Mihevc, A., Prelovšek, M., Zupan, H.N., Eds.; Karst Research Institute: Postojna, Slovenija, 2010; pp. 14-19.

9. Glazier, D.S. Springs. In Likens GE (ur.) Encyclopedia of Inland Waters; Elsevier: Oxford, UK, 2009; Volume 1, pp. 734-755.

10. Goldschmidt, T. Water mites (Acari, Hydrachnidia): Powerful but widely neglected bioindicators-A review. Neotrop. Biodivers. 2016, 2, 12-25. [CrossRef]

11. Gerecke, R.; Martin, P.; Gledhill, T. Water mites (Acari: Parasitengona: Hydrachnidia) as inhabitants of groundwater-influenced habitats-Considerations following an update of Limnofauna Europaea. Limnologica 2018, 69, 81-93. [CrossRef]

12. Pešić, V.; Savić, A.; Jabłońska, A.; Michoński, G.; Grabowski, M.; Bańkowska, A.; Zawal, A. Environmental factors affecting water mite assemblages along eucrenon-hypocrenon gradients in Mediterranean karstic springs. Exp. Appl. Acarol. 2019, 77, 71-486. [CrossRef] [PubMed]

13. Smith, I. Water mites (Acari: Parasitengona: Hydrachnida) of spring habitats in Canada. Mem. Entomol. Soc. Can. 1991, 155, 141-167. [CrossRef]

14. Gerecke, R.; Di Sabatino, A. Water mites (Acari, Hydrachnellae) and spring typology in Sicily. Crunoecia 1996, 5, 35-41.

15. Illies, J. Limnofauna Europaea; Gustav Fischer: Stuttgart, Germany; New York, NY, USA, 1978; pp. 1-532.

16. Pešić, V.; Asadi, M.; Cimpean, M.; Dabert, M.; Esen, Y.; Gerecke, R.; Martin, P.; Savic, A.; Smit, H.; Stur, E. Six species in one: Evidence of cryptic speciation in the Hygrobates fluviatilis complex (Acariformes, Hydrachnidia, Hygrobatidae). Syst. Appl. Acarol. 2017, 22, 1327-1377. [CrossRef]

17. AQEM Consortium. Manual for the application of the AQEM system. In A Comprehensive Method to Assess European Streams Using Benthic Macroinvertebrates Developed for the Purpose of the Water Framework Directive; Version 1.0; European Commission: Duisburg, Germany, 2020.

18. Davids, C.; Di Sabatino, A.; Gerecke, R. Chelicerata: Araneae, Acari I. In Chelicerata: Araneae, Acari I. Süßwasserfauna von Mitteleuropa 7/2-1; Bartsch, I., Davids, C., Deichsel, R., Eds.; Spektrum Akademischer: Heidelberg, Germany, 2007; pp. 241-333.

19. Di Sabatino, A.; Gerecke, R.; Gledhill, T.; Smit, H. Chelicerata: Acari II. In Süßwasserfauna von Mitteleuropa 7/2-2; Gerecke, R., Ed.; Spektrum: Heidelberg, Germany, 2010; pp. 1-216.

20. Gerecke, R.; Gledhill, T.; Pešić, V.; Smit, H. Chelicerata: Acari III. In Süßßwasserfauna von Mitteleuropa 7/2-3; Spektrum: Heidelberg, Germany, 2016; pp. 1-417.

21. Tuzovskij, P. Key to Deutonymphs of Water Mites; Akademia Nauka Moscow, UdSSR: Moscow, Russia, 2000. 
22. Ter Braak, C.J.F.; Šmilauer, P. CANOCO Reference Manual and User's Guide: Software for Ordination (Version 5.0); Microcomputer Power: Ithaca, NY, USA, 2012.

23. Clarke, K.R.; Gorley, R.N. PRIMER V6: User manual/tutorial. In Plymouth: Primer-E; Plymouth Marine Laboratory: Plymouth, UK, 2006; pp. 1-192.

24. TIBCO Software Inc. Statistica (Data Analysis Software System), Version 13. Available online: http: //statistica.io (accessed on 7 May 2019).

25. Goldschmidt, T. Environmental parameters determining the water mite communities in Costa Rican freshwater habitats. Exp. Appl. Acarol. 2004, 34, 171-197. [CrossRef] [PubMed]

26. Goldschmidt, T. Water mites (Acari, Hydrachnidia) in tropical springs—Diversity, specificity, monitoring possibilities. Verh. Des. Int. Ver. Limnol. 2009, 30, 669-672. [CrossRef]

27. Martin, P.; Stur, E. Parasite-host associations and life cycles of spring-living water mites (Hydrachnidia, Acari) from Luxembourg. Hydrobiologia 2006, 573, 17-37. [CrossRef]

28. Pozojević, I.; Pešić, V.; Gottstein, S. Two water mite species (Acari: Hydrachnidia) from karst springs new for the fauna of Croatia with notes on distribution and environmental preferences. Nat. Croat. 2019, 28, 417-424. [CrossRef]

(C) 2020 by the authors. Licensee MDPI, Basel, Switzerland. This article is an open access article distributed under the terms and conditions of the Creative Commons Attribution (CC BY) license (http://creativecommons.org/licenses/by/4.0/). 